\title{
Universiteit
}

Leiden

The Netherlands

\section{Colonial conquest in central Madagascar: who resisted what?}

Ellis, S.; Abbink, G.J.; Bruijn, M.E. de.; Walraven, K. van

\section{Citation}

Ellis, S. (2003). Colonial conquest in central Madagascar: who resisted what? In G. J. Abbink, M. E. de. Bruijn, \& K. van Walraven (Eds.), African dynamics (pp. 69-86). Leiden [etc.]: Brill. Retrieved from https://hdl.handle.net/1887/9618

Version: $\quad$ Not Applicable (or Unknown)

License: $\quad$ Leiden University Non-exclusive license

Downloaded from: $\quad$ https://hdl.handle.net/1887/9618

Note: To cite this publication please use the final published version (if applicable). 


\title{
Colonial conquest in central Madagascar: Who resisted what?
}

\author{
Stephen Ellis
}

A rising against French colonial rule in central Madagascar (1895-1898) appeared in the 1970s as a good example of resistance to colonialism, sparked by France's occupation of Madagascar. Like many similar episodes in other parts of Africa, it was a history that appeared, in the light of later African nationalist movements, to be a precursor to the more sophisticated anti-colonial movements that eventually led to independence, in Madagascar and elsewhere. In the light of the later history of nationalism, however, it is instructive to revisit the rising of the menalamba in Madagascar and to reconsider the episode.

On 22 November 1895, less than two months after French colonial troops had taken the Merina royal capital at Antananarivo in their conquest of Madagascar, there was a violent uprising in a district immediately to the west of Madagascar's premier city. The violence was directed at local officials of the royal government and at prominent Christian converts, but what most shocked Europeans was the murder of other Europeans: the local missionary family, British Quakers who had lived in Madagascar for more than twenty years. William Johnson, his wife Lucy and their baby daughter were hacked to death by a mob of perhaps a thousand people. French troops retaliated by laying waste the area surrounding the scene of the Johnsons' murder, burning houses and killing people more or less randomly in the belief that severe punishment would prevent any repetition.' Nevertheless, throughout the following weeks there were reports from many parts of central Madagascar of local disputes of various

1 S. Ellis, The Rising of the Red Shawls: A Revolt in Madagascar, 1895-1898 (Cambridge, 1985). 
sorts getting out of control, fights breaking out at markets, unpopular village officials being attacked and church buildings being damaged. In many places there were reports of exceptionally serious raids by cattle rustlers, sometimes in bands hundreds strong, and some including Malagasy army deserters with breech-loading rifles. There were fantastic rumours of impending doom and disaster.

The French were officially committed to propping up the royal administration of Queen Ranavalona III, previously regarded by European states as the ruler of Madagascar although the state that she reigned over had never in fact controlled more than half the island. Her government was also, to a degree the French had underestimated, in an advanced state of collapse. The establishment of a protectorate was the result of lobbying by the French Foreign Ministry, which had recently achieved some success with a similar policy in Tunisia and which in principle wished to avoid any more expensive form of rule in Madagascar. This policy was contested by others in the administration in Paris, however, including some in the war ministry, members of the French expeditionary force in Madagascar and the small number of French private citizens who were already living on the island, most of them dirt-poor Creoles from the island of Réunion.

In March 1896 there was a wave of attacks on administrative posts of the Merina royal government in several parts of the central highland region. The attacks were obviously coordinated, to the point that French officials in Madagascar sensed at once that this was of a different order from ordinary cattle-stealing or even from the attack on the Johnson family four months previously. Rumours spread that the rising was secretly being organized by Queen Ranavalona, the figurehead of the protectorate government, or by some of her courtiers. There were even rumours that British missionaries were in league with the insurgents in spite of the murder of some of their own. Although these rumours were essentially false, the fact that they were so widely believed says much about the nature of the insurrection as well as about divisions among the French. This was, after all, the period of the Dreyfus affair, when French men and women were bitterly split on a great range of issues, especially those concerning the role of the army.

The insurgents, who later became known as menalamba (red shawls), were to keep some semblance of organization until 1898 and posed a serious

${ }^{2}$ S. Ellis, 'The Political Elite of Tananarive and the Revolt of the Menalamba: The Creation of a Colonial Myth in Madagascar, 1895-1898', Journal of African History XXI, 11 (1980), 219-34. Among the documents that Dreyfus was accused of having given to the German government were those relating to the French invasion of Madagascar!

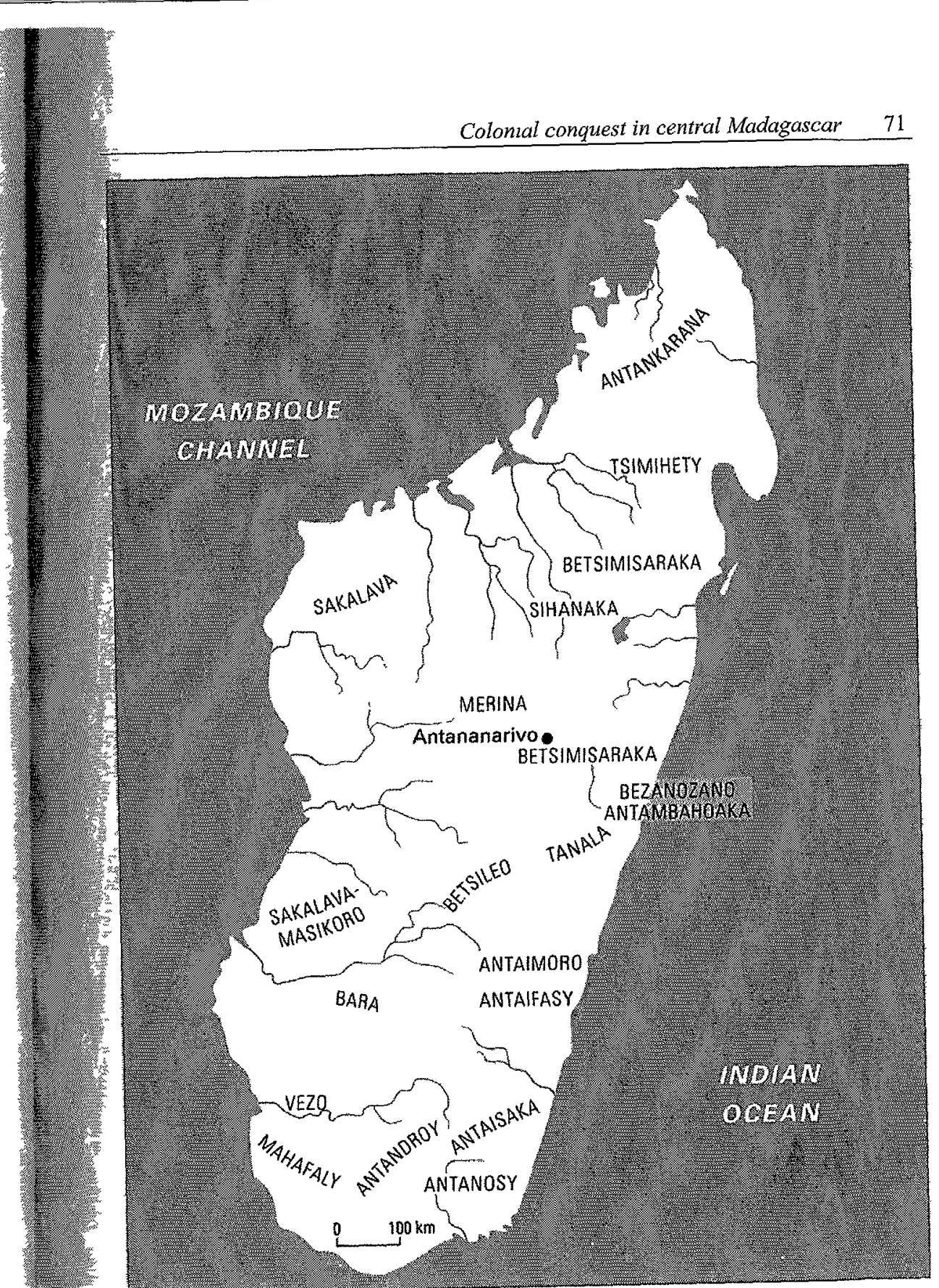

Map 3.1 Ethnic groups of Madagascar 
embarrassment to French rule. In August 1896, a senior French official on the island reckoned that 300,000 people were living in areas under menalamba control. ${ }^{3}$ In retrospect, however, it is clear that there was never the remotest chance of the menalamba forcing the French to abandon their aim of exercising formal control over Madagascar. On the contrary, the seriousness of the uprising caused the government in Paris to develop a more rigorous policy, declaring Madagascar to be a French colony and sending a military governor with wide-reaching powers, General Gallieni, to sort out the problem.

While as many as 100,000 Malagasy may have died from violence and hunger during the uprising, the number of deaths of French soldiers and civilians, more from disease than enemy action, was in the hundreds. The enormous difference in casualty figures is evidence of the superiority of French arms but perhaps also indicates something about the menalamba. It may, for example, suggest that the insurgents did not conceive of themselves as a singleminded anti-colonial resistance movement. Before exploring this idea further, however, it is useful to describe briefly the literature produced by Africanist historians on collaboration and resistance between Africans and colonial occupiers.

\section{Collaboration and resistance}

Particular historical objects or phenomena - in this case, the menalamba rising - are liable to differing interpretations as times change and new generations ask questions about the past that seem most important or interesting in the light of current circumstances. Madagascar remained a French colony from the time of the menalamba until 1960, and for 12 years afterwards its first postindependence government continued with many of the policies inherited from colonial times. For almost 80 years, there seemed little reason for anyone involved in public life to remember the menalamba other than as a reactionary opposition to colonial rule by the least educated part of the population of central Madagascar. Moreover, many Malagasy historians were Christians, who were often nostalgic about the independence of pre-colonial Madagascar but could not easily sympathize with those like the menalamba who had burned churches and killed pastors.

It was only after the uprising of 1972, when Madagascar acquired a radical nationalist and socialist government, that the memory of the menalamba was rehabilitated. The government officially commemorated the tragic anti-French insurrection of 1947, which resembled the menalamba movement in many ways,

\footnotetext{
${ }^{3}$ P. Bourde, quoted in Ellis, Rising of the Red Shawls, 97.
}

claiming it as a precursor of its own nationalist struggle. ${ }^{4}$ The first modern book on the menalamba was published in 1976 by a Malagasy radio journalist who had devoted a series of programmes to the subject, representing the menalamba as nationalists who had fought to preserve the island from foreign rule, and including a whole series of revolts between 1895 and 1905 within this category. 5 It comes as no surprise that the menalamba should have been identified as nationalists or proto-nationalists at a time when Madagascar was governed by a radical regime that based its legitimacy on its rejection of neocolonialism. In the years immediately after independence there were many African governments and their supporters that identified themselves in public with earlier anti-colonial movements. An obvious place to start looking for a radical anti-colonial pedigree was in the records of those people who had fought against European intruders in the period of conquest or of early colonial rule. This was the golden age of African nationalism: the period from 1945 until, perhaps, the independence of Zimbabwe in 1980. It was a period when it was growingly apparent to people all over the world that colonialism had become an anachronism, a politically unjust dispensation whose time had passed. Investigating the extent to which Africans had resisted colonialism was thus both interesting and politically useful.

It was in roughly these circumstances that collaboration and resistance to colonial rule were constituted as a field of formal historical inquiry by historians of Africa intent on recovering the historical records of a continent that Europeans had often dismissed as being without history. ${ }^{6}$ A pioneering work in the new history of African nationalism was Terence Ranger's book on resistance to colonial rule in Rhodesia, published in 1967 when Ranger was working at the University of Dar es Salaam's history department, a nursery of talented scholars, in a city that was one of the main diplomatic hubs of the southern African liberation struggle. ${ }^{7}$

From the beginning, one of the key themes of research on this subject was the connection between resistance to the imposition of colonial rule (dubbed 'primary resistance' by Terence Ranger) and modern nationalist movements ('secondary resistance'). ${ }^{8}$ One inclination of nationalist historians was to explore the connections between these two generations of resistance movements

${ }^{4}$ Ibid. $158-62$.

5 J. Rasoanasy, Menalamba sy Tanindrazana (Antananarivo, 1976).

${ }^{6}$ A notion usefully explored by E. Wolf, Europe and the People Without History (Berkeley \& London, 1982)

${ }^{7}$ T. Ranger, Revolt in Southern Rhodesia, 1896-1897 (London, 1967).

${ }^{8} \mathrm{~T}$. Ranger, 'Connexions between "Primary Resistance Movements" and Modern Mass Nationalism in East and Central Africa', Journal of African History, 9 (1968), 437-53, $631-41$. 
with a view to determining the extent to which later nationalist movements might have been the descendants of earlier resisters, or at least with the aim of exploring the ways in which nationalists drew inspiration from earlier examples of opponents of colonial rule. Although some prominent commentators pointed out that the notions of 'collaboration' and 'resistance', redolent of Europe in the Second World War, were too stark and lacking in nuance to do justice to the complexity of most African histories, ${ }^{9}$ studies based on this approach formed a prominent school of writing in African history.

When I began in 1976 to investigate the history of the menalamba for my $\mathrm{PhD}$ thesis, it seemed obvious that the movement should in the first instance be considered as a case of resistance to colonial rule. I assumed that further and more penetrating questions would proceed from this starting-point. It was taken for granted by most Africanist historians at that time that people whose countries were being invaded by foreign troops intent on taking formal control would be naturally inclined to resist this process, so there was little point in asking why they were fighting. Ranger's work suggested that the key questions were instead related to the ways in which resisters organized themselves, whether and in what senses they could be regarded as nationalists, what the results of their struggle were, and what effects it had on later nationalist movements. I soon found, however, that the question of who precisely the menalamba were and what motivated them was of crucial importance as they seemed more intent on fighting certain other Malagasy than they did on fighting the French or Europeans more generally. Equally, there were large numbers of Malagasy who showed no interest in the menalamba, who were from the centre and centre-north of this massive island, more than two-and-a-half times the size of Britain.

I found myself being drawn not so much forward in time, as Ranger's model would imply, in order to look at the effects of the menalamba on later nationalism, but rather felt myself pulled backwards, to an examination of what sort of society the menalamba came from. The so-called Kingdom of Madagascar was something of a juridical fiction. In the eighteenth century, a powerful state had emerged in the central region known as Imerina that had subsequently expanded rapidly through military conquest. Successive rulers of Imerina after 1817 had called themselves kings and queens of Madagascar, although in fact they had never succeeded in conquering the whole island. It was apparent that the expansion of the Merina state had produced all sorts of tensions

\footnotetext{
9 For example J Suret-Canale, "Résistance" et "Collaboration" en Afrique Norre Coloniale', in Etudes Africaines Offertes à Henri Brunschwing (Parıs, 1982), 319-31. It is notable that Suret-Canale was a veteran communist who had resisted German
} occupation in France during the Second World War. and enmities tending towards social disintegration. Throughout the nineteenth century, central Madagascar had witnessed a series of movements of resistance the royal government in Antananarivo including in the form of physical flight, ceasional armed risings, and endemic banditry. The effective overthrow of this government by French forces in 1895 removed the last remaining constraints to alarge-scale, violent, settling of scores.

Seen from this perspective, the menalamba movement was not only, or perhaps not even primarily, resistance to French colonization but arose from a mass of unresolved conflicts whose roots lay in the pre-colonial history of Madagascar. Another historian, Gwyn Campbell, has emphasized this aspect to the point of doubting whether the menalamba were nationalists at all, ${ }^{10}$ but this is to ignore the politics of the menalamba. There is clear evidence from their own letters that the menalamba were nationalists in the sense that many of them had a conscious notion of Madagascar as a political unity that should be governed by a single monarch, whom they often called Mpanjakan iMadagasikara. This imagined community under one political rule qualifies as nationalism. Madagascar was rather different from many societies of mainland Africa in that the Merina Kingdom - alias the Kingdom of Madagascar acquired, before colonial times, many of the hallmarks of what contemporary Europeans regarded as a state. It had a monarch situated in a capital city who had an overwhelming armed force at his (or, after 1828, her) disposal and a high degree of control over a substantial territory, one with an industrious and generally fixed population. The second king of the ruling dynasty, Radama I (1809-28) was an autocrat who welcomed contacts with the British diplomats and missionaries who sought influence in Madagascar at the end of Britain's global war against France. King Radama had heard of Napoleon Bonaparte and developed an explicit ambition to be a conqueror like his hero, seeing the whole of Madagascar as his natural domain. He was formally recognized by Britain as the King of Madagascar in a treaty signed in 1817. Later, France, the United States and other Western countries all recognized the government in Antananarivo as the legitimate ruler of Madagascar, bringing it within the juridical field of the leading powers. Radama and his successors adopted a number of European institutions and technologies to strengthen their power, including literacy in the Latin alphabet, the institution of a state bureaucracy, and a standing army. They even made an attempt at establishing their own arms

${ }^{10}$ This is emphasized in a series of articles by G. Campbell: 'Missionaries, Fanompoana and the Menalamba Revolt in Late Nineteenth Century Madagascar', Journal of Southern African Studies, 15, 1 (1988), 54-73; 'The Menalamba Revolt and Brigandry in Imperial Madagascar, 1820-1897', International Journal of African Historical Studies, 24, 2 (1991), 259-91; 'The History of Nineteenth Century Madagascar: Le "Royaume" or "l'Empire"?', Omaly sy Anto, 33-6 (1991-2), 331-79. 
and munitions factories. In 1868-9 the Queen and the Prime Minister converted to Protestant Christianity and made it into the state religion, and shortly afterwards established a system of compulsory primary education.

Contemplating this chronicle 20 years ago, not only did it seem reasonable to describe the policy of successive Merina sovereigns and their leading ministers as a form of nationalism but also it was clear that elements of a nationalist ideology had taken root among at least some of their subjects. Even taking account of the decline in African nationalism as a coherent political force since the $1980 \mathrm{~s}$, which has suggested that its roots are perhaps more complex than once seemed to be the case, it still seems to me to be justified to describe the programme of the nineteenth-century Merina government in this way. The main objection that has been made to this is that the government in Antananarivo never succeeded in establishing control over more than two-thirds of Madagascar, and that it extended its rule by the military conquest of other parts of the island that owed allegiance to independent dynasties and other ethnic groups outside the Merina heartland. It was, it has been argued, not a national government at all, but only claimed to be such. According to this argument, the Merina state had conquered a number of independent peoples, thus being an empire rather than a national state. ${ }^{11}$ But the fact that the kingdom in Antananarivo inflicted terrible suffering in its campaign to conquer all of Madagascar, that it was never fully successful in this aim, and that the government increasingly came under the control of a clique of families from the central highlands does not detract from the identification of this government as nationalist in orientation. Part of the significance of the menalamba movement was that it demonstrated how deeply the nationalist idea had penetrated the society of the central highlands, the most densely populated area of Madagascar. It is not necessary for historians to consider nationalism as a noble or liberating force. Moreover, the various political formations throughout the island that were conquered by the Merina state did not represent ethnic groups in the sense that was to become general later, under colonial rule. The same language is spoken in the form of mutually intelligible dialects all over Madagascar, and every part of the island was influenced over the centuries by other parts of the island. The different named clusters of population at the beginning of the nineteenth century consisted of people of diverse origin who had adopted collective names in recognition of their political allegiance. ${ }^{12}$ Many of the menalamba who claimed they were fighting to restore a properly

"Campbell, 'Nineteenth Century Madagascar'.

${ }^{12}$ C. P. Larson, 'Desperately Seeking the Merina (Central Madagascar): Reading Ethnonyms and their Semantic Fields in African Identity Histories', Journal of Southern African Studies, 22, 4 (1996), 541-60.

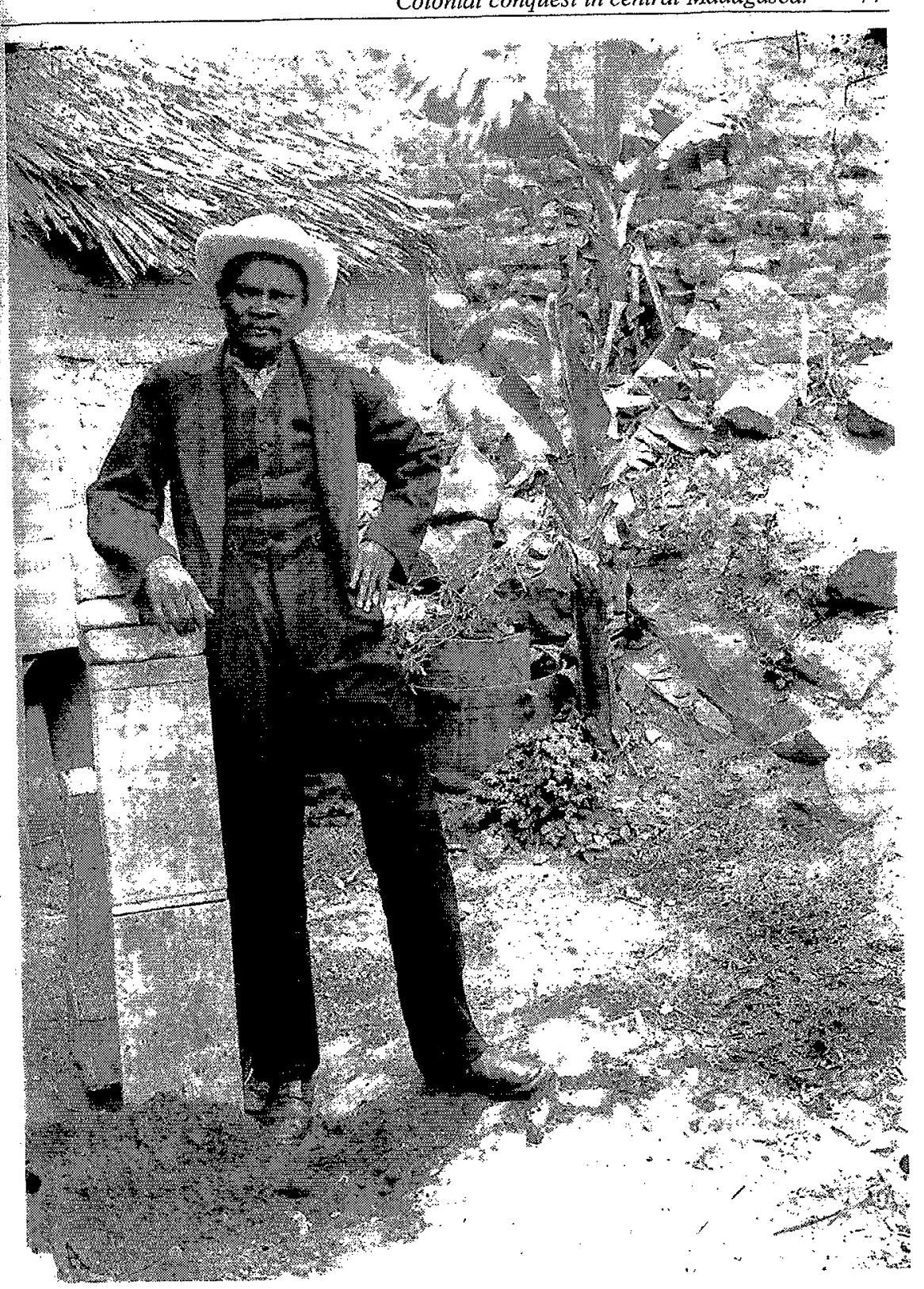

The menalamba leader Rabezavana, Madagascar, 1897

Copyright: FTM Antananarivo 
functioning sovereignty to Madagascar were not ethnic Merina in the sense of being descended from families that had lived for generations in the central highlands around Antananarivo. This is the case, for example, with one of the two most important menalamba leaders, Rabezavana.

\section{What were the menalamba resisting?}

In short, the key question that has been asked of the menalamba is what precisely they were resisting. It is clear that this was not only a movement of resistance to colonial rule. It was also a campaign against an unpopular government that had habitually used extreme brutality, particularly in the recruitment of forced labourers, and which in its earlier years had organized massive military expeditions that enslaved people on a large scale and coincidentally caused numerous deaths from disease and hunger among its own conscripts. After 1869 this same regime was associated with an official Protestant church that came to be widely resented. The abuses of this state, regarded in the emerging system of international law as independent and sovereign, provoked the anger of the menalamba, to be sure, just as they had provoked outbreaks of dissent, often in the form of flight or banditry, in earlier years. But the menalamba were more than bandits, recalcitrants or people goaded beyond endurance by material demands. They had a clear political ideology which they expounded in the messages they wrote to each other, in their public proclamations and in the actions they took. They aimed to restore the monarchy, if not in Antananarivo then in another holy place of their tradition, in what they regarded as its proper form. This was a movement of purification. The insurgents over a very large swathe of central and northern Madagascar were not resisting the principle of the Kingdom of Madagascar, as it was officially known and as the menalamba themselves sometimes called it, but the way in which it had been administered. Indeed, in September 1896 a large gathering of menalamba from different parts of central Madagascar chose one of their number to be the new king of Madagascar, to replace Queen Ranavalona whom they now regarded as illegitimate due to her relations with the French. ${ }^{13}$ This may be contrasted with anti-colonial risings in other parts of Madagascar, notably in the south and southeast in 1904-5, which had no organizational and little ideological affinity to the menalamba movement. These were risings by people who did not acknowledge the sovereignty of the kings and queens of Imerina and had no ambition to construct a single state in Madagascar. They were motivated most obviously by a refusal to submit to

\footnotetext{
${ }^{13}$ Ellis, Rising of the Red Shawls, 93.
}

French rule and by protests against forced labour and colonial exactions and against the abolition of slavery.

\section{The penetration of capitalism}

That the self-styled Kingdom of Madagascar, ruled by Malagasy until its demise in 1895-6, was regarded by Europeans as a sovereign entity was to a considerable extent due to the growing influence of Britain in the Indian Ocean. Foreign influence in the formation of states in Madagascar was not in itself new. Successive political constructions on the island, going back many centuries, had been formed from the interaction between existing rulers and foreigners bringing in powerful political technologies, often of a ritual type. ${ }^{14}$ The European traders who frequented the coasts of Madagascar after the sixteenth century, buying slaves in exchange for guns, silver coins and manufactured goods, can be placed in a history of foreigners whose goods and skills were used as materials for political construction. However, King Radama's treaty with Britain in 1817 and the arrival of British missionaries in Antananarivo three years later was difficult. It signalled the alliance of a powerful Malagasy king who was developing an ambition to conquer the whole island with a European state (which had its own political project) able to exert unprecedented power in the western Indian Ocean. The British governor in Mauritius in 1817 had his own reasons for encouraging Radama to become king of Madagascar, to be an ally against the French and to guarantee an end to slave exports from the whole island. Unlike earlier generations of European slave-dealers and pirates, the British wanted not just to trade but also to build a new state, for which they offered technical, military and financial help.

Eighty years after the creation of an Anglo-Merina alliance, the menalamba were resisting a form of governance that, while administered by Malagasy, also represented a growing European influence. For many of the Queen of Madagascar's subjects the most obvious manifestation of this was the Christian church, considered by many to be an essentially foreign form of worship. After the $1860 \mathrm{~s}$, members of the Merina elite, for whom the church was a key structure of political administration, were increasingly likely to dress in European clothes, live in European-style houses and have a taste for imported consumer goods. The material aspects of the church, including its use for the recrutment of forced labourers and army conscripts and for raising a variety of taxes, were, before 1895 , indistinguishable from its spiritual and ritual aspects.

${ }_{14}$ See, in particular, the introduction to F. Raison-Jourde, Les Souverains de Madagascar. L'Histoire Royale et ses Résurgences Contemporaines (Parıs, 1983). 
The attempt to construct a Christian state of Madagascar after 1869 , that was to cause such suffering before its collapse, was itself both a product and gauge of the growth of European influence that had a far-reaching effect even before the colonial period. The menalamba were fighting a Malagasy elite that they considered to have used brutal and unjust methods to enrich themselves and to have made common cause with European aggressors. Again, this is apparent in their own letters and proclamations.

If the menalamba sprang from a population that had been abused and economically exploited before the imposition of colonial rule, their greatest enemies were the members of the Christian elite who had inflicted this on them. Royal ministers and officials, encouraged by missionaries to consider European styles of consumption and living as virtuous, used their position to increase their own wealth and power. This observation could easily lead to a Marxist-tinged analysis of the pre-colonial elite of Madagascar as a comprador class, whose economic interest in collaborating with foreign capital determined their political stance. ${ }^{15}$ Such a point of view came to be quite widely applied to the analysis of resistance in Africa, raising the question of whether people who fought against colonial rule were resisting the imposition of foreign domination as such, or whether the key determinant was perhaps not in fact the incursion of capitalism. In the case of Madagascar, capitalism could be said to have had a clear effect before colonial times on the growth of markets and of a property-owning elite that traded with the West and made use of international credit. ${ }^{16}$ Studies of resistance to capitalism in this vein often took, in the hands of Marxist scholars such as Eric Hobsbawm, ${ }^{17}$ a greatly expanded notion of political action, based on the proposition that infractions of the legal or moral order are tantamount to an attack on the political order thought to underpin them. Hence, some studies of African reactions to Western encroachment took an extremely broad definition of what constituted 'resistance', sometimes considered to include not only organized military activity against colonial forces but also tax evasion, the avoidance of forced labour, flight, so-called 'social banditry' and other manifestations of a refusal to accept the official colonial order. In this way Africanists came to identify, through documents located in dusty colonial archives, a whole stream of draft and tax dodgers, vagrants and others who were now considered as potential proto-nationalists. ${ }^{18}$

${ }^{15}$ A fully-fledged Marxist analysis is P. Boiteau, Madagascar. Contributıon à l'Histoire de la Nation Malgache (Paris, 1958).

${ }^{16}$ Cf. T. Ranger, 'The People in African Resistance: A Review', Journal of Southern African Studies, 4 (1977), 125-46.

${ }_{17}^{17}$ E. Hobsbawm, Bandits (Harmondsworth, 1985).

${ }^{18}$ For example A.F. Isaacman in collaboration with B. Isaacman, The Tradition of Resistance in Mozambique: Antt-colonial Acttvity in the Zambezi Valley, 1850-1921
An analysis based rigidly on an identification of people's economic interests, An analysis based rigidly on to historical facts, and particularly the strong political or cultural factor in people's behaviour. (Indeed, what is culture except an attribution of meaning to action?) It behoves an analyst to look at the cultural forms of behaviour, or in this instance of expressions of opposition to government. It was demonstrated on many occasions in the nineteenth century the most effective form of opposition to the government in Antananarivo that the most effective form of opposition to the government in more distant parts of Madagascar this might be a king having an established legitimacy at least in one locality, this might be a king hava kings on the west coast of the island, but within the area which had come under the control of the Merina kings the only politically which had come the based on an alternative king, such as the agitation surrounding the crown prince in the late $1850 \mathrm{~s}$, or the revolt in western Imerina in 1863-4 where insurgents claimed to be following a king who had miraculously resurrected or escaped assassination. 19

The menalamba revolt initially convinced French colonial officials that the idea of a Malagasy nation was the construct of a Merina ethnic group (or perhaps just of its more privileged strata) that was inveterately anglophile, and perhaps just of its more privileged strata) the fore to be found in other parts of the island. This led General Gallieni, the military strong man who defeated the rising and attempted to create a model colony in Madagascar, to enunciate what he called a politique des races, intended to promote the sentiment of solid ethnic allegiances to France in other parts of the island. His idea was to govern ethnic allegiances to France in other parts of the istand homogeneous administrative units, all of which he hoped would be better disposed to France than the Merina were. This which he however, soon encountered the realization that those people deemed to be ethnic Merina were the most numerous group on the island, constituting be ethnic Merina we the most num In addition, their traditions of literacy perhaps a third of the total populati and submission to bureaucratic government and the logic of markets and cash payments made the Merina in some ways more useful colonial subjects and auxiliaries than were the inhabitants of other parts of the island. This, in time, led to the curious situation where families of the Merina bourgeoisie, who were generally well placed to derive advantage from colonization, were sending their children into the liberal professions and, later, into the upper reaches of the administration, but still retained the reputation of being fundamentally anti-

(London, 1976). This is also the approach taken in regard to Madagascar by Campbell, op. cit.

${ }_{19}$ F. Raison-Jourde, Bible et Pouvorr à Madagascar au XIXe Siècle (Par1s, 1991), 197289. On the agitation around the supposed escape of Radama II, see R. Delval, Radama II, Prince de la Renaissance Malgache (Paris, 1972). 
colonial. Prominent leaders of the nationalist movement which emerged in the mid-1940s were Merina aristocrats, including even relatives of the last queen. ${ }^{20}$ The prospect of an independence that would restore to power some of the old slave-owning families of the Merina elite created a powerful counter-movement in some other parts of the island but most noticeably among the descendants of slaves in Imerina. ${ }^{21}$

Even by the 1940 s it was clear that Malagasy nationalism was complex enough to include several different strains, only some of which could be considered as belonging to the same tradition as the menalamba. At its heart was not only an aspiration to independence but also a social struggle between Malagasy. The history of the menalamba and the policies used by the colonial government to defeat the movement meant that the memory of the independent kingdom of Madagascar became an inspiration to nationalists able to point to a pre-colonial history of national government. Simultaneously however, this history was divisive, since it reminded some social groups of the exactions they had suffered under a government dominated by a ruling group of families from the central highlands. After 65 years of colonial rule, the island's populations became closer than before to ethnic groups in the modern sense, with a clear sense of regional identity and a reinvented history to fit.

\section{What is left of the resistance debate?}

I have argued elsewhere that a great deal of writing about wars in Africa from the beginning of the colonial period until the late twentieth century was influenced by the coincidence of Africa's political independence with the establishment of African history as an accepted academic sub-discipline, a process which began in Europe in the 1940s, and arguably slightly earlier in the United States by way of African-American studies. ${ }^{22}$ The literature on early resistance to colonial rule is a good illustration of how this synchronism encouraged a particular view of the past based on a sharp dichotomy between what historians have considered colonial and foreign and what they have identified as authentically African. An important aspect of historical research is

${ }^{20}$ See the biographical notes in J. Tronchon, L'Insurrectoon Malgache de 1947 (Paris, 1974), 207-19.

${ }^{21}$ J.-R. Randriamaro, PADESM et Luttes Poltttques à Madagascar (Parıs, 1997). 22 S. Ellıs, 'Africas Wars of Liberation: Some Historiographical Reflections', in P.
Konings, W. van Binsbergen \& G. Hesseling (eds), Trajectotres de Libération en Afrique Contemporaine (Par1s, 2000), 69-91. For a more extensive survey, J.C. Miller, 'History and Africa/Africa and History', Amencan Historical Review, 104, 1 (1999), 1- o situate people as far as possible in their own time by trying in the first instance to understand what motivates them in their own terms. The danger in identifying any group of resisters of colonial rule as proto-nationalists is its inherent risk of suggesting that they were motivated by ideas that they did not in fact have. Hence, one of the main flaws in the method of identifying primary and secondary resisters of colonialism, and attempting to incorporate them into asingle nationalist narrative, is the risk of anachronism which it carries.

By the same token, it is probably because of the rapidly changing fortunes of African nationalism in recent years that there have been so few studies of eollaboration and resistance since the 1980s. African nationalism no longer appears to be as clearly heroic or progressive as it once did. If the debate on collaboration and resistance to colonialism ended rather abruptly, before any consensus had been reached or key questions had been really clarified, it is perhaps because of a number of contemporary developments which have served to complicate our view of the past. I would suggest that the most important of these is the onset of a new generation of wars. For example, it was in 1982 that armed clashes between rival Zimbabwean nationalist movements began in earnest, and within a short time Zimbabwean government forces were systematically killing thousands of Matabele people on suspicion of supporting the political opposition. ${ }^{23}$ Although the details of these events were not widely known at the time, it was plain that they raised a whole series of questions regarding the nature of ethnicity and factional conflict within the nationalist movements in Zimbabwe, the country which Ranger in particular had placed at the centre of debates on collaboration and resistance. This implied a need for a reformulation of discussions about which components of African societies were most opposed to colonial rule, and on what grounds, and what the consequence of their opposition was. In recent years the number of internecine conflicts in Africa has increased. War in Africa has come to seem such a disturbing phenomenon not only because of the number of victims it leaves behind, but precisely because it can no longer be so easily fitted into an explanatory framework.

The relationship to nationalism of many current wars in Africa is unclear. Armed conflicts such as those taking place in Liberia, Sierra Leone, Sudan, Congo and elsewhere today are widely perceived in the West as representing a new generation of wars thought to have been caused either by the end of the Cold War or by the impact of globalization, or a combination of the two. In an alarming number of analyses, these wars are considered a sign of reversion to an age-old barbarism said to be characteristic of Africa. This point of view is so

${ }^{23}$ K.P. Yap, 'Uprooting the Weeds: Power, Ethnicity and Violence in the Matabeleland Conflict, 1980-1987', PhD thesis, University of Amsterdam (2000). 
prejudiced as to require no further comment. ${ }^{24}$ In the most eloquent treatments Africa's new generation of wars is bracketed together with those in the Balkans, central Asia and elsewhere as part of a wave of so-called 'new wars'. This has the considerable merit of considering Africa as an integral part of the world rather than as an enclave. 25

Such an analysis supposes that a historic rupture occurred in or about the late 1980 s or early 1990 s which resulted in a new wave of wars, and that these recent wars are of a radically new type. This view, though, does not really stand up to scrutiny, at least in the case of Africa. ${ }^{26}$ It is true that dictators were kept in power in Liberia and Somalia with US assistance until 1990 and 1991 respectively, and that these regimes collapsed more or less with the ending of the Cold War when the US government decided that it was no longer in its own interest to continue these relationships. In much the same way, the Mengistu regime in Ethiopia also finally collapsed in 1991 after the withdrawal of Sovie support. In all of these cases, however, military violence had already been both large-scale and systematic for years, taking the form, for example, of major conventional campaigns in Ethiopia, of substantial ethnic purges in Liberia in 1985, and of the aerial bombardment of a major Somali city, Hargeisa, in 1988. In other words, many of Africa's most serious wars actually began well before the end of the Cold War, even if these conflicts took on new forms in the 1990s.

Thus, despite arguments to the contrary, Africa's current armed conflicts go back further than the last decade and the end of the Cold War. Indeed, as shown in the introduction to this volume, wars of the current generation are often directly linked to (or they are even continuations of) struggles that occurred around the time of independence. ${ }^{27}$ This should cause us to ask some new questions about the violence which occurred during colonial times and which once seemed to be most convincingly explained as resistance to colonialism. The nature of the colonial relationship, which has been the subject of much recent research in the field of representations and identities, now appears more complex than it did three or four decades ago. The colonial bond did not consist

${ }^{24}$ See criticism of the 'New Barbarısm' thesis by P. Richards, Fighting for the Rain Forest: War, Youth and Resources in Sierra Leone (Oxford \& Portsmouth NH, 1996), xiii-xxix.

${ }^{25}$ Notably M. Kaldor, New and Old Wars Organized Violence in a Global Era (Oxford, 1999).

${ }^{26}$ The subject of an unpublished analysis by R. Marchal \& C. Messiant, 'Une Lecture Symptomale de Quelques Théorisations Récentes des Guerres Civiles', presented at a meeting in July 2001 of the Centre for Defence Studies, Kings College, London/Centre d'Efudes et de Recherches Internationales, Paris, joint study-group on African wars. ${ }^{27}$ Noted in the introduction to C. Clapham (ed.), African Guerrillas (Oxford, 1998), 118 . entirely of colonial exploiters and suffering natives. Likewise, the aftermath of 6olonial rule in Africa was not simply a contest of continued dependency versus self-determination. There are grounds, therefore, to reconsider the whole history dif violence during colonial rule and even up to very recent times within a single perspective, taking account not only of the colonial element in such conflicts but also of the social struggles within African societies.

OOne aspect of earlier research on collaboration and resistance which has been vindicated time after time, however, is the extent to which modern African Ilationalists have invoked memories of those earlier African leaders who were hown to have fought against white colonizers. In Zimbabwe, as Ranger demonstrated, the same word - chimurenga - was widely used to designate both struggles. In nationalist historiography, figures such as Samory Touré in central West Africa, Rainilaiarivony in Madagascar or Sultan Rabîh in Chad have been represented as patriots or proto-nationalists whose military feats could be explained primarily by their wish to avoid being incorporated into Europeanruled states. ${ }^{28}$

These and many other historical fighters against colonialism do indeed live on in popular memory but many of them appear to have left a highly ambiguous legacy. Rainilaiarivony, the last prime minister of the pre-colonial kingdom of Madagascar, is remembered today in Madagascar but not often as a protonationalist hero. Samory Touré, to take a clearer example, was certainly regarded by French colonizers as a major opponent, and he undoubtedly built up a powerful military force which dominated areas of modern Guinea, Liberia, Sierra Leone and Côte d'Ivoire in the last two decades of the nineteenth century. French colonization of the Sahel proceeded only after his final defeat. Samory's conquests, however, were accompanied by brutal slave-raiding by his redoubtable cavalry and the forced conversion to Islam of peoples living on the historic frontier of Malinke penetration of the rain-forest. ${ }^{29}$ Ahmed Sékou Touré, the president who ruled Guinea with such ferocity from 1958 to 1984, claimed to be a direct descendant of Samory. There are probably as many West Africans today who have heard stories about Samory as a Malinke slave-raider from the north as those who know him as a fierce resister of colonialism.

At a time when politics in Côte d'Ivoire and Liberia are marked by a serious split between Malinke and others, the particular associations attached to Samory's name are of obvious relevance. Nationalists could perhaps argue that state-building, whether in Africa or elsewhere, is generally a bloody business

${ }^{28}$ See, for example, Les Africalns (Paris, 1977), an eight-volume set edited by C -A. Julıen with contributions from leading historians, and published by Jeune Afrique.

${ }_{29}^{9}$ Y. Person, Samory, 3 vols (Dakar, 1968, 1975). My own observations concerning memories of Samory are based on interviews in Liberia and Côte d'Ivorre. 
since it proceeds via an acquisition of a monopoly of violence, and that this no more disqualifies a Samory as a nationalist hero than it disqualifies a Bonaparte or a Bismarck. This is true enough, but it is through their historic legacies that such famous nationalists are judged. The question is not how much force these people used but what their legacy is. This suggests a need to analyse the nature of memory in societies in which historical traditions are still largely orally transmitted. The findings of such an analysis would then tell us much about any particular African nationalism.

Perhaps we are better placed now than a generation ago to realize how seldom colonial rule took the form of a sudden attack by colonizers on societies previously innocent of commercial contacts with westerners. African societies had, in the past, been affected by joint interests or joint ventures in the form of the slave trade, for example. If the debate on resistance to colonial rule and its legacies is to be continued, perhaps what is most needed are new studies of various parts of Africa that dispassionately analyse what we now know of the nature of modern nationalism. 